Electrochimica Acta, 2007, Volume 52, Issue 12, Pages 4032-4042.

Print ISSN: 0013-4686

Online ISSN: 1873-3859

DOI: 10.1016/j.electacta.2006.11.019

(c) 2006 Elsevier Science Ltd. All rights reserved.

http://www.elsevier.com/wps/find/journaldescription.cws_home/205/description\#description

\title{
A study of the mechanisms of corrosion inhibition of AA2024-T3 by vanadates using the split cell technique
}

\author{
M. Iannuzzi, G.S. Frankel
}

Fontana Corrosion Center, The Ohio State University

J. Kovac

Slovenian National Building and Civil Engineering Institute, Llubljana, Slovenia

\begin{abstract}
The mechanisms of corrosion inhibition of AA2024-T3 by vanadates were studied in this work using the split cell technique and polarization curves. The electrochemical behavior of clear solutions containing metavanadates and orange solutions containing decavanadates was clearly distinctive. Injection of metavanadates to the cathode side of the different split cell setups greatly reduced the galvanic current, indicating a potent inhibition of the oxygen reduction kinetics. The galvanic current never exhibited a transient current peak, suggesting that metavanadates inhibit AA2024-T3 corrosion by a mechanism that does not involve electrochemical reduction. Injection of metavanadate to the anode side of the different split cells had no effect on the galvanic current. Injection of orange decavanadate to the cathode side of the AA2024-T3 split cell resulted in a large current peak, associated with the electrochemical reduction of decavanadate. However, decavanadates did not impart significant corrosion protection.
\end{abstract}

\section{Introduction}

Aluminum alloy 2024-T3 (AA2024-T3) is a heat-treatable high strength aluminum alloy that is used as fuselage skin and structural material in aircraft design. The microstructure of high strength alloys is composed of second phase and intermetallic particles and it tends to be rather complex [1,2]. The good mechanical properties of heat-treatable aluminum alloys are a direct consequence of this heterogeneous microstructure, which provides relatively high strength via precipitation hardening [1-3].

The susceptibility of aluminum alloys to localized corrosion strongly depends on the distribution and electrochemical properties of the intermetallic compounds and second phase particles [4-10]. A great effort has been made to analyze the corrosion behavior of high strength aluminum alloys. In particular, AA2024-T3 is among the most extensively studied alloys, and the mechanisms of corrosion have been debated in the literature [5, 7-17].

Due to the susceptibility to localized corrosion, aluminum alloys for aerospace applications are protected from the aggressive environment using multi-layered coating systems based on the chemistry of chromates [18-25]. It has been shown that the formation of a $\mathrm{Cr}^{3+}$ monolayer inhibits oxygen and further $\mathrm{Cr}^{6+}$ reduction [18, 27-32]. Debate still exists regarding the control over the anodic dissolution of active phases [33]. Nevertheless, the fast and irreversible formation of the $\mathrm{Cr}^{3+}$ layer seems to play the major role [20,33,34]. In addition, chromate systems exhibit the critical property of self-healing or active corrosion protection. 
Active corrosion protection is likely a consequence of the $3+/ 6+$ mixed oxidation state of the $\mathrm{Cr}$ film [19, 20, 22, 30, 34-37]. Labile $\mathrm{Cr}^{6+}$ can be released from the coating and migrate to a damaged region where electrochemical reduction to $\mathrm{Cr}^{3+}$ may occur, protecting the surface from further corrosion [20, 30, 37].

Despite the fact that a significant effort is being made, a suitable candidate for chromate replacement remains to be discovered [18]. The complexity of the aqueous chemistry of some proposed alternatives such as vanadates has made this work very challenging [38, 39].

The coordination chemistry of vanadates in aqueous solutions involves several protonation/deprotonation reactions, as well as polymerization to form oligomers of varied molecular weight, depending upon $\mathrm{pH}$ and concentration [40-44]. A detailed characterization of the system was presented elsewhere [39, 45]. In short, as-prepared solutions of $\mathrm{NaVO}_{3}$ dissolved in $0.5 \mathrm{M} \mathrm{NaCl}$ remain colorless. According to ${ }^{51} \mathrm{~V}$ nuclear magnetic resonance spectroscopy (NMR), clear metavanadate solutions contain monovanadate $\left(\mathrm{V}_{1}\right)$, divanadate $\left(\mathrm{V}_{2}\right)$, tetravanadate $\left(\mathrm{V}_{4}\right)$ and pentavanadate $\left(\mathrm{V}_{5}\right)$ species [46-50]. Polymerization of these oligomers to form orange decavanadates $\left(\mathrm{V}_{10}\right)$ occurs during acidification [46, 47, 49-52]. Thus, if the $\mathrm{pH}$ of clear solutions is adjusted to $\mathrm{pH} 4$, only signal from $\mathrm{V}_{10}$ is detected by ${ }^{51} \mathrm{~V} \mathrm{NMR}$, indicating complete polymerization of $\mathrm{V}_{1}-\mathrm{V}_{5}$. Readjusting the $\mathrm{pH}$ of the orange electrolytes to $\mathrm{pH} 8.71$ partially depolymerizes $\mathrm{V}_{10}$ to give $\mathrm{V}_{2}, \mathrm{~V}_{4}$, and $\mathrm{V}_{5}[39,45] .{ }^{51} \mathrm{~V}$ NMR also showed that the monovanadates are present exclusively in clear metavanadate electrolytes. In contrast, $V_{10}$ and $V_{4}$ are the predominant species in orange solutions [39, 45].

The electrochemical behavior of AA2024-T3 in clear metavanadate solutions containing monovanadates but no decavanadates was markedly different than in orange solutions containing decavanadates but no monovanadates [39]. Orange solutions containing decavanadates did not lower the rate of oxygen reduction reaction (ORR) significantly. In contrast, the presence of monovanadates remarkably reduced the rate of ORR to an extent comparable to values reported for chromates [39]. Long term exposure and polarization resistance $\left(R_{\mathrm{P}}\right)$ evaluation confirmed the potent inhibition exerted by the monovanadates. Only small pits were observed after 14 days of exposure to solutions containing approximately $4 \mathrm{mM} \mathrm{V}_{1}(10 \mathrm{mM} \mathrm{NaVO}$ total) and $0.5 \mathrm{M}$ $\mathrm{NaCl}$. The polarization resistance $\left(R_{\mathrm{P}}\right)$ in such conditions ranged from 300 to $1100 \mathrm{k} \Omega \mathrm{cm}^{2}$ over a $24 \mathrm{~h}$ period. Nevertheless, the mechanisms of inhibition remain to be determined. In this paper the mechanisms of vanadate inhibition of AA2024-T3 corrosion in $0.5 \mathrm{M} \mathrm{NaCl}$ are investigated using the split cell technique. The split cell technique measures the galvanic current flowing between two samples in two cells separated by a glass frit [33]. The samples can be different or the environments can be different, resulting in one side acting as a net anode and the other side as the net cathode. The galvanic current measurement enables the study of inhibition mechanisms with no need for the external application of potential. This approach has been used successfully by Clark et al. to investigate inhibition by chromates [33].

$\mathrm{Al} / \mathrm{Cu}$ cells produce an almost complete segregation of anodic and cathodic reactions. In contrast, AA2024/Cu and AA2024/AA2024 cells produce an imperfect separation. The net galvanic current, $I_{\text {net }}$, can be expressed as the balance of the following currents:

$$
\left|I_{\text {net }}\right|=\left|I_{\mathrm{C} 1}-I_{\mathrm{A} 1}\right|=\left|I_{\mathrm{A} 2}-I_{\mathrm{C} 2}\right|(1)
$$

where $I_{\mathrm{C} 1}$ and $I_{\mathrm{A} 1}$ represent the total cathodic and anodic currents on the electrode on side 1 of the split cell and $I_{\mathrm{C} 2}$ and $I_{\mathrm{A} 2}$ are the anodic and cathodic currents on side 2, respectively. For the $\mathrm{Al} / \mathrm{Cu}$ couple, $I_{\mathrm{CAl}}$ and $I_{\mathrm{ACu}}$ are negligible and $I_{\text {net }}$ is representative of the total rate of reaction on 
each electrode. For the AA2024/AA2024 couple, anodic and cathodic reactions occur on both electrodes. Therefore, $I_{\text {net }}$ is lower than the actual rates of the anodic reaction (corrosion) on the anode and the cathodic reaction (oxygen reduction) on the cathode.

Understanding the inhibition of AA2024-T3 corrosion in complex systems such as vanadates could aid in the discovery of alternative pigments or new conversion coating processes. Therefore, the objective of this work is to analyze the inhibition mechanisms of clear solutions containing monovanadates and of orange solutions containing decavanadates.

\section{Experimental}

\section{1. $\quad$ Materials and sample preparation}

Sodium vanadium oxide, $98 \% \mathrm{NaVO}_{3}$, and reagent-grade sodium chloride were obtained from Sigma-Aldrich. All solutions were prepared with $18.2 \mathrm{M} \Omega \mathrm{cm}$ deionized water.

Unless otherwise noted, metavanadate solutions were prepared by dissolving $\mathrm{NaVO}_{3}$ in $0.5 \mathrm{M} \mathrm{NaCl}$ and adjusting the as-prepared $\mathrm{pH}$ to the higher value of 8.71. Orange solutions containing decavanadates were prepared by acidification of the clear solutions to $\mathrm{pH} 4$, and subsequent re-adjustment to $\mathrm{pH}$ 8.71. Prepared in this fashion, monovanadates $\left(\mathrm{V}_{1}\right)$ are present only in clear solutions and decavanadates $\left(\mathrm{V}_{10}\right)$ are present only in orange electrolytes [39]. For simplicity, these solutions will be referred to as orange decavanadate and clear metavanadate solutions, respectively, even though the former solutions also contain some metavanadates. Two different AA2024-T3 panels (nominal composition 3.8-4.9\% Cu, 1.2-1.8\% Mg, 0.3-0.9\% Mn, $0.5 \% \mathrm{Fe}, 0.5 \% \mathrm{Si}, 0.25 \% \mathrm{Zn}, 0.1 \% \mathrm{Cr}, 0.05 \% \mathrm{Ti}$, balance $\mathrm{Al}$ ), were tested with 1 and $5 \mathrm{~mm}$ thickness, respectively. The samples were mounted in epoxy resin, exposing the rolled surface, ground through 1200 grit SiC papers (Buehler), and polished with 3 and $1 \mu \mathrm{m}$ diamond paste (Buehler). Ethyl alcohol ( $<0.2 \%$ water) was used as lubricant during all the surface preparation stages to minimize corrosion damage during grinding and polishing. Pure $\mathrm{Cu}(99.95 \%)$ and pure Al (99.999\%) were cut from $50 \mathrm{~mm}$ plates, mounted in epoxy resin and polished following similar procedures.

\subsection{Split cell technique}

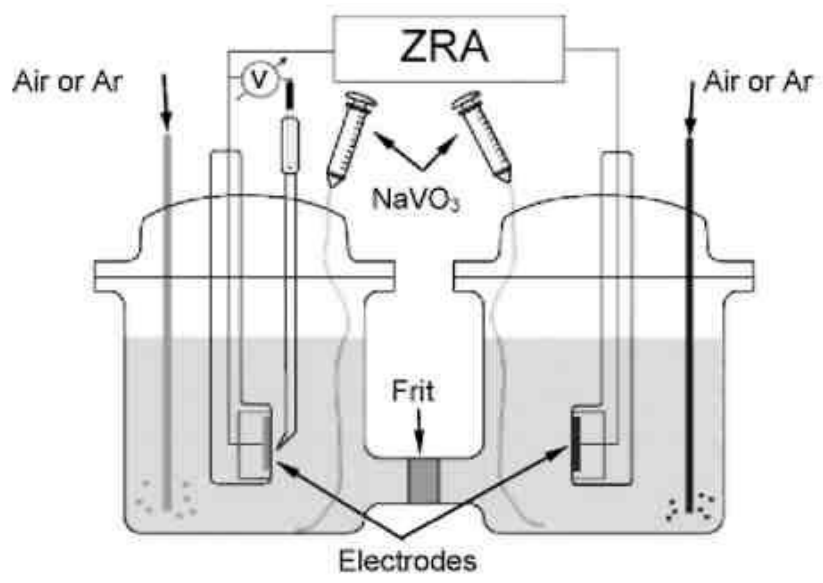

Fig. 1. Schematic representation of the split cell configuration utilized in this research. Compartments separated by a glass frit allowing ionic current to flow. Potential was measured at the anode side. 
Fig. 1 shows the split cell set up. The exposed area of each electrode was $0.3 \mathrm{~cm}^{2}$. Galvanic current and potential were monitored using a Gamry PC3/300 potentiostat in zero resistance ammeter (ZRA) mode. Negative current represents flow of electrons from the anode to the cathode. The potential of the couple was measured at the anode side. A potential drop existed between the anode and cathode; however the small current and good electrolyte conductivity of the $0.5 \mathrm{M} \mathrm{NaCl}$ solution limited the extent of the ohmic drop to less than $3 \mathrm{mV}$.

$\mathrm{Al} / \mathrm{Cu}, \mathrm{AA} 2024 / \mathrm{Cu}$ and AA2024/AA2024 cells were tested. The effects of additions of clear metavanadate or orange decavanadate solutions were evaluated by injecting into the base solution of $0.5 \mathrm{M} \mathrm{NaCl}$ a concentrated solution made of clear or orange $0.5 \mathrm{M} \mathrm{NaCl}+150 \mathrm{mM}$ $\mathrm{NaVO}_{3}$, respectively, which resulted in a final concentration of $5 \mathrm{mM} \mathrm{NaVO}$ total after dilution. The final $\mathrm{pH}$ independent of speciation was approximately 7.6 in all cases. Experiments were repeated at least in triplicate.

\subsection{Polarization curves}

All tests were carried out using either a Gamry PC3/300 or a VoltaLab PGP-201 potentiostat. A platinum mesh counter-electrode and a SCE reference electrode were used in all experiments. A Luggin capillary filled with an agar-agar gel made with $0.5 \mathrm{M} \mathrm{NaCl}$ was used. Samples were cleaned and degreased with ethyl alcohol before testing. Each experiment was repeated at least in triplicate. Anodic polarization experiments were performed in aerated and deaerated conditions. Deaeration was achieved by $1 \mathrm{~h}$ Ar degassing and gentle stirring. After $1 \mathrm{~h}$, samples were lowered into the electrolyte and the OCP was measured for $15 \mathrm{~min}$. The flow of $\mathrm{Ar}$ was reduced but not stopped during the experiment. The potential sweep started $10 \mathrm{mV}$ below OCP and was stopped when the current density reached $2 \mathrm{~mA} / \mathrm{cm}^{2}$. The total exposed area was approximately $1 \mathrm{~cm}^{2}$. Experiments with $\mathrm{NaVO}_{3}$ were scanned at $0.3 \mathrm{mV} / \mathrm{s}$.

Cathodic polarization experiments were carried out in solutions that were bubbled with air for $1 \mathrm{~h}$ prior to the experiment and stirred during the experiment to generate a more reproducible limiting current for the ORR. The potential sweep started $10 \mathrm{mV}$ above OCP and was stopped when the current density reached $-2 \mathrm{~mA} / \mathrm{cm}^{2}$. A scan rate of $1 \mathrm{mV} / \mathrm{s}$ was used and the total exposed area was approximately $1 \mathrm{~cm}^{2}$.

\section{Results}

\subsection{Split cell technique}

Before performing split cell experiments with injection of the vanadate solutions, it was of interest to analyze the response of the cell setup under different aeration/deaeration and stirring conditions. Effects of aeration/deaeration cycles in an $\mathrm{Al} / \mathrm{Cu}$ split cell are shown in Fig. 2. The solid and dashed lines indicate the effects of controlling aeration conditions on the $\mathrm{Cu}-$ cathode and Al-anode side, respectively. During the initial $15 \mathrm{~min}$, both sides of the split cell were in stagnant, air-exposed conditions. At $15 \mathrm{~min}$, air was introduced to the Cu-cathode. At 30 min, air flow was stopped and replaced by Ar gas on the same side of the split cell. Finally, at 45 min the bubbling gas was changed back to air.

The net galvanic current flowing in the stagnant air exposed $\mathrm{Al} / \mathrm{Cu}$ split cell was between 10 and $15 \mu \mathrm{A}$. Introducing air to the $\mathrm{Cu}$-cathode increased the galvanic current to $45-50 \mu \mathrm{A}$. Deaeration of the $\mathrm{Cu}$-cathode side reduced the electron flow to approximately $5 \mu \mathrm{A}$, and was 
accompanied by a reduction in the cell potential from -0.73 to $-1.05 \mathrm{~V}$ SCE. Re-introduction of air on the Cu-cathode increased the negative current back to approximately $-45 \mu \mathrm{A}$ and the potential to $-0.75 \mathrm{~V}$ SCE. Stirring had similar effects on the split cell response. Aeration and convection changes on the Al-anode side produced no measurable changes in galvanic current and cell potential. Galvanic current was only affected by changing aeration and convection on the Cu-cathode side. In good agreement with Clark et al. [33], these findings show that the net galvanic current, and consequently the extent of anodic dissolution, was controlled by oxygen reduction at the $\mathrm{Cu}$-cathode.
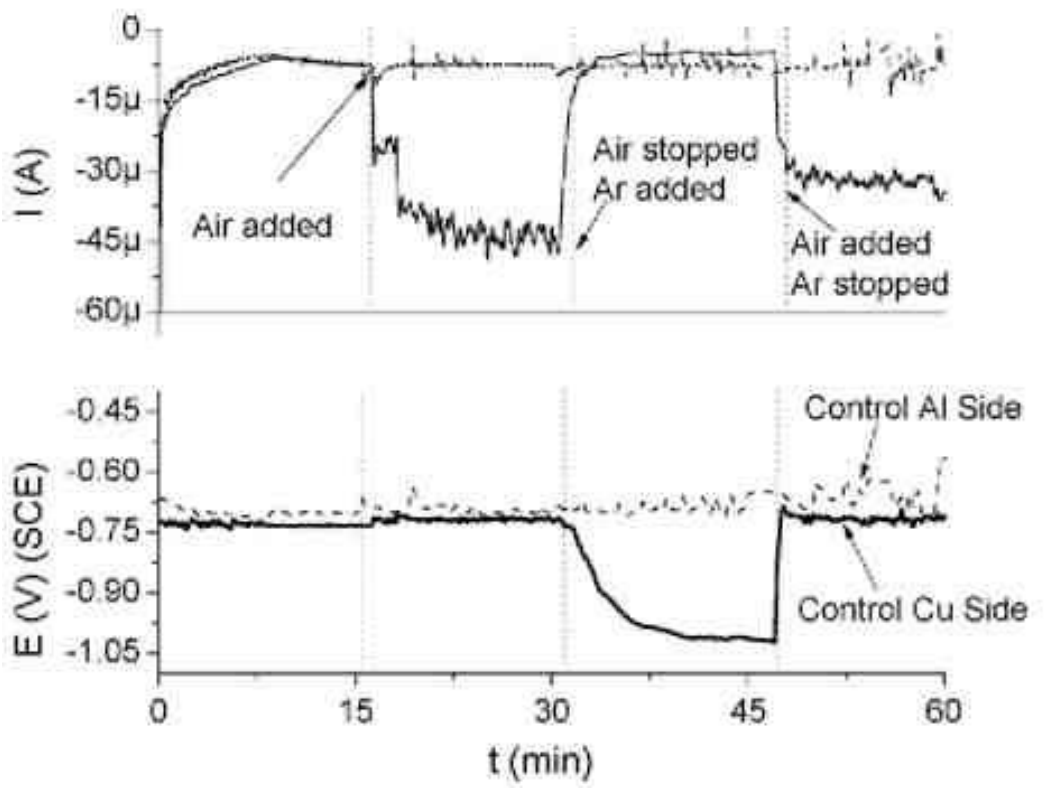

Fig. 2. Effects of aeration-deaeration cycles on an $\mathrm{Al} / \mathrm{Cu}$ couple in $0.5 \mathrm{M} \mathrm{NaCl}$. Aeration control on cathode (Cu) (solid line) and aeration control on anode (Al) (dashed line). The uncontrolled side was exposed to air in each case.

The response of the cell setup to the injection of $\mathrm{Cr}^{6+}$ ion was also investigated. In agreement with Clark et al., injection of chromate to the cathode of different split cells was characterized by a sharp current spike associated with the electrochemical reduction of $\mathrm{Cr}^{6+}$ to $\mathrm{Cr}^{3+}[33,53]$. Uncontrolled injection of solution can also affect the galvanic current by altering convection. To minimize such problems, solution was injected slowly using a syringe connected to a plastic tube of small diameter, Fig. 1. No artifacts were detected when the solution was injected in this fashion [45].

The effects of injecting clear metavanadate solution to an $\mathrm{Al} / \mathrm{Cu}$ split cell are shown in Fig. 3. In the experiment presented in Fig. 3, aeration control began at 5 min, with air bubbled on the $\mathrm{Cu}$-cathode and $\mathrm{Ar}$ on the $\mathrm{Al}$-anode. Aeration on the cathode side resulted in a large increase of the galvanic current from approximately -10 to $-40 \mu \mathrm{A}$. Injection of clear metavanadate solution to the Al-anode at 15 min produced no appreciable change in the galvanic current and cell potential. Injection of clear metavanadate solution to the $\mathrm{Cu}$-cathode at 25 min produced a reduction in galvanic current of about $37 \%$ but no change in cell potential was observed. In contrast to chromates, no current peak associated with reduction of vanadium was found after injection of clear metavanadate solution to the cathode side. Increasing the concentration of inhibitor by a second injection at $60 \mathrm{~min}$ did not have an extra beneficial effect and the galvanic 
current remained at about $27 \mu \mathrm{A}$. Similar results were found when the metavanadate solution was first injected to the $\mathrm{Cu}$-cathode. It is interesting to note that the $\mathrm{Al}$ anode suffered severe pitting during the experiments. After removal from solutions, pits were covered by a dark yellow product that was enriched in vanadium. These findings were also reported by other authors and might be attributed to the formation of a vanadium gel due to the acidic $\mathrm{pH}$ of the pits [38]. Table 1 summarizes the $\mathrm{Al} / \mathrm{Cu}$ split cell results.
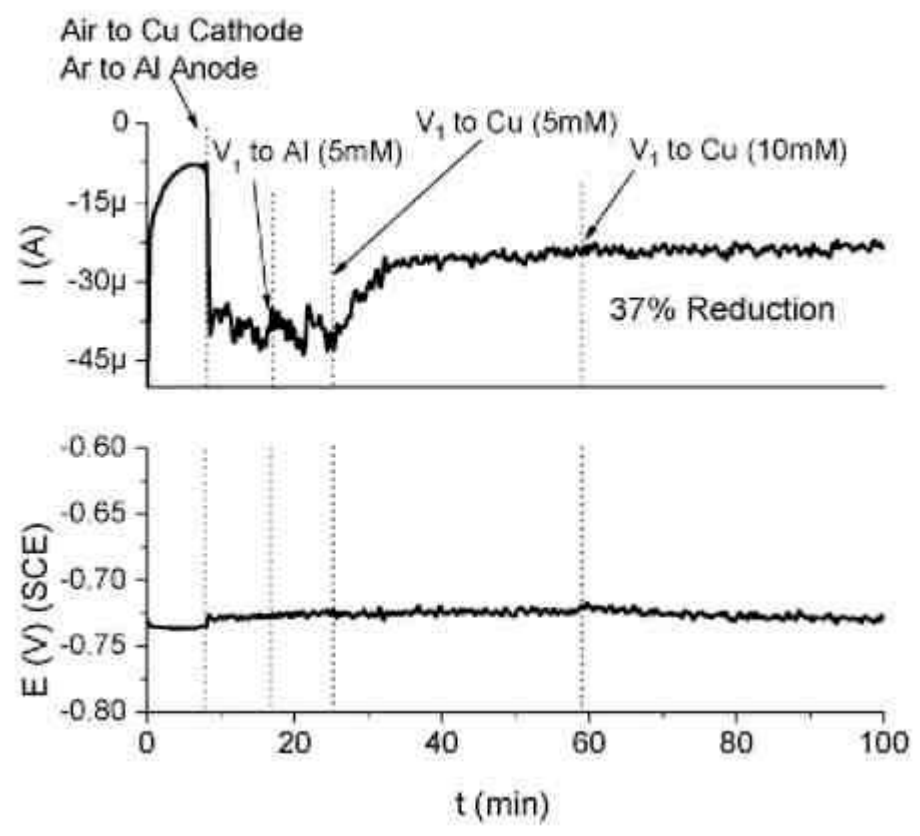

Fig. 3. Al/Cu split cell. Clear metavanadate solutions injected into anode (Al) first and then cathode (Cu) twice.
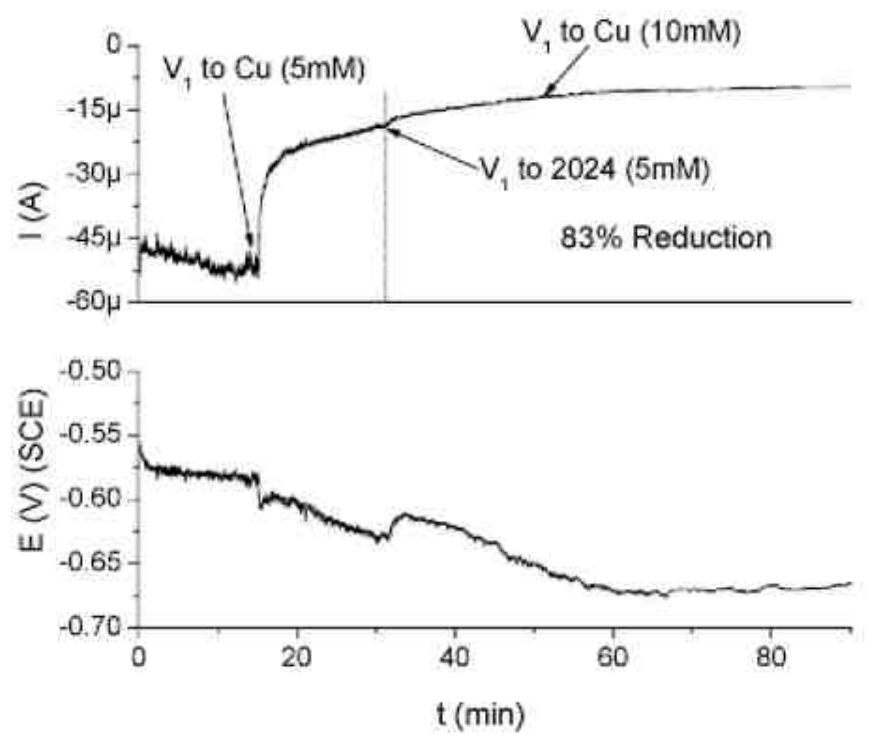

Fig. 4. AA2024/Cu split cell. Clear metavanadate solution injected into cathode $(\mathrm{Cu})$ first, to the anode (AA2024T3) later and finally to the cathode $(\mathrm{Cu})$ to make $10 \mathrm{mM} \mathrm{NaVO}_{3}$ total. 
In the $\mathrm{Al} / \mathrm{Cu}$ split cell, the anodic and cathodic reactions were almost fully separated with ORR only supported on the $\mathrm{Cu}$ side. As explained previously, the situation is slightly different in the AA2024/Cu split cell. Due to the large difference in open circuit potentials between $\mathrm{Cu}$ and AA2024-T3, the Cu side will still act as the net cathode and the AA2024-T3 side will act as the net anode in the AA2024/Cu split cell. However, Fe-containing intermetallic compounds (IMCs) at the surface of AA2024-T3 can serve as local cathodes supporting the ORR even when the AA2024-T3 side is anodically polarized by the $\mathrm{Cu}$ electrode. The effects of injecting clear metavanadate solutions to the AA2024/Cu split cell are shown in Fig. 4. Deaeration of the AA2024-T3 side and aeration of the $\mathrm{Cu}$ side started at the beginning of the experiments, giving a galvanic current that varied from -35 to $-47 \mu \mathrm{A}$. In the experiment represented in Fig. 4, injection of clear metavanadate to the $\mathrm{Cu}$-cathode side at about 15 min produced a sharp reduction in galvanic current of about 83\%, and no current peak was observed. At 30 min, injection of the inhibitor to the anode side produced no change in galvanic current and cell potential. A subsequent injection of clear metavanadate into the cathode side at approximately 50 min did not have a significant effect. Table 2 summarizes the results obtained for the AA2024/Cu couple.

Table 1

Summary of potential and cell current with and without $5 \mathrm{mM}$ clear metavanadate additions for the Al-Cu couple

\begin{tabular}{|c|c|c|c|c|c|c|}
\hline \multirow[t]{2}{*}{ Condition } & \multicolumn{3}{|c|}{ Predicted from polarization plots } & \multicolumn{3}{|c|}{ Measured from split cell test } \\
\hline & $E_{\text {Couple }}(\mathrm{V})$ & $i_{\text {Couple }}\left(\mu \mathrm{A} / \mathrm{cm}^{2}\right)$ & \% reduction & $E_{\text {Couple }}(\mathrm{V})$ & $i_{\text {Couple }}\left(\mu \mathrm{A} / \mathrm{cm}^{2}\right)$ & 㛟 reduction \\
\hline $\mathrm{Al}$ (no-inhibitot) $\mid \mathrm{Cu}$ (no-inhibitor) & -0.69 & 292 & - & -0.71 & -143 & - \\
\hline $\mathrm{Al}\left(\mathrm{V}_{1}\right) \| \mathrm{Cu}$ (no-inhibitor) & -0.69 & 292 & - & -0.72 & -126 & - \\
\hline $\mathrm{Al}$ (no-inhibitor) $\mid \mathrm{Cu}\left(\mathrm{V}_{1}\right)$ & -0.71 & 78.4 & 73 & -0.73 & -9136 & 36 \\
\hline $\mathrm{Al}\left(\mathrm{V}_{1}\right) \| \mathrm{Cu}\left(\mathrm{V}_{1}\right)$ & -0.71 & 78.4 & 73 & -0.73 & -9136 & 36 \\
\hline
\end{tabular}

Table 2

Summary of potential and cell current with and without $5 \mathrm{mM}$ clear metavanadate additions for the A2024/Cu couple

\begin{tabular}{|c|c|c|c|c|c|c|}
\hline \multirow[t]{2}{*}{ Condition } & \multicolumn{3}{|c|}{ Predicted from polarization plots } & \multicolumn{3}{|c|}{ Measured from split cell test } \\
\hline & $E_{\text {Couple }}(\mathrm{V})$ & $i_{\text {Couple }}\left(\mu \mathrm{A} / \mathrm{cm}^{2}\right)$ & \% reduction & $E_{\text {Couple }}(\mathrm{V})$ & $i_{\text {Couple }}\left(\mu \mathrm{A} / \mathrm{cm}^{2}\right)$ & \% reduction \\
\hline 2024 (no-inhibitor) |Cu (no-inhibitor) & $-0.571-0.63$ & 271.83 & - & -0.59 & -136 & - \\
\hline $2024\left(\mathrm{~V}_{1}\right) \| \mathrm{Cu}$ (no-inhibitor) & -0.54 & 229.1 & - & -0.58 & -103 & - \\
\hline 2024 (no-inhibitor) $\| \mathrm{Cu}\left(\mathrm{V}_{1}\right)$ & -0.63 & 46.26 & 83 & -0.61 & -33 & 77 \\
\hline $2024\left(\mathrm{~V}_{1}\right) \| \mathrm{Cu}\left(\mathrm{V}_{1}\right)$ & -0.556 & 25.11 & 90 & -0.61 & -33 & 77 \\
\hline
\end{tabular}

Separation of anodic and cathodic reaction on the AA2024/AA2024 split cell was achieved by differential aeration. The side deaerated by purging with Ar acted as a net anode, and the side bubbled with air as a net cathode. Separation was not perfect due to the presence of IMCs on both sides and the galvanic current was not a measure of the total corrosion rate, Eq. (1). The effects of injecting clear metavanadate solution to the AA2024/AA2024 split cell are shown in Fig. 5. Aeration control started from the beginning of the experiment, resulting in the initial galvanic current of about $-170 \mathrm{nA}$. Even though the galvanic current observed in the AA2024/AA2024 split cell was substantially lower than the galvanic current measured in $\mathrm{Al} / \mathrm{Cu}$ and AA2024/Cu split cells, such values still indicate a net flow of electrons from the anode (deaerated side) to the cathode (aerated side). Injection of clear metavanadate to the anode side at 
15 min did not result in a reduction in galvanic current. The current actually increased slightly. Injection of the inhibitor to the cathode (aerated side) at 30 min significantly reduced the galvanic current by about $87 \%$. Similar results were obtained when the clear metavanadate solution was first introduced to the cathode side. Table 3 summarizes the results obtained for the AA2024/AA2024 split cell.
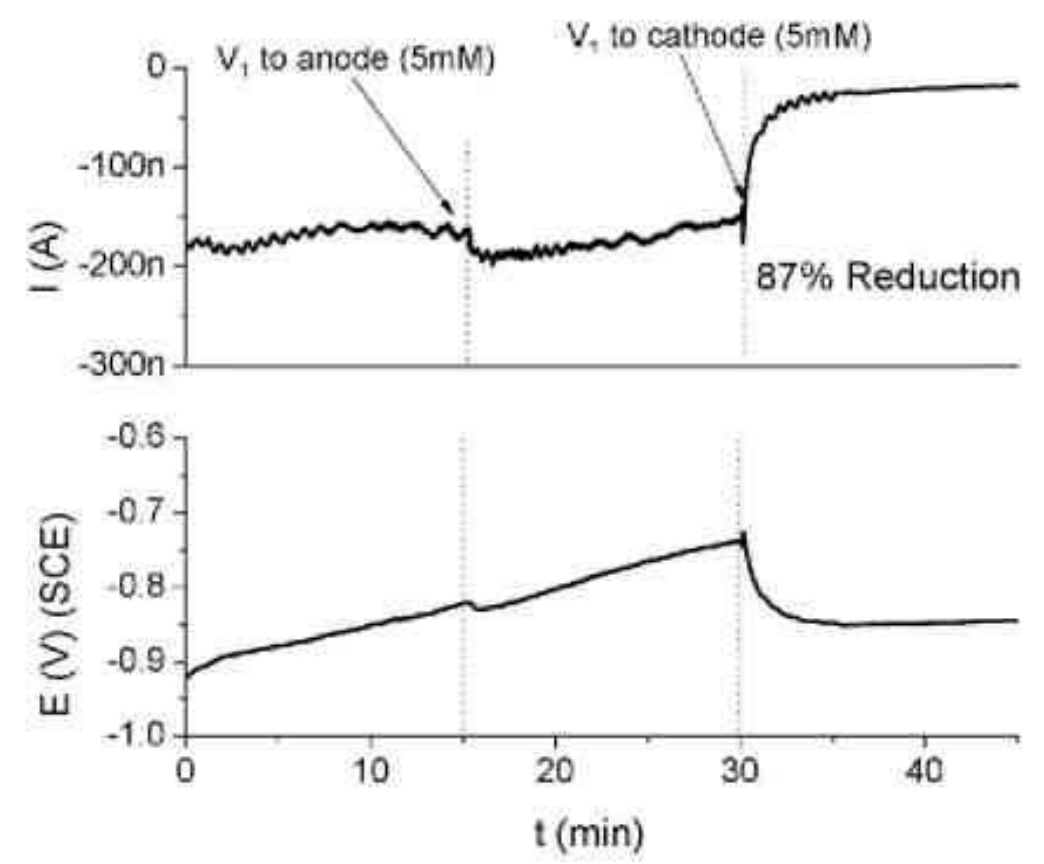

Fig. 5. AA2024/AA2024 split cell. Clear metavanadate solution injected into the anode first (deaerated side) and to the cathode later (aerated side).

It is interesting to note that in all the experiments the potential of the cell was noticeably lower than the pitting potential of AA2024 in $0.5 \mathrm{M} \mathrm{NaCl}$ and varied between -1.05 and $-0.9 \mathrm{~V}$ SCE. Optical microscopy performed after the experiment revealed the presence of corrosion attack on both the anode and the cathode samples, Fig. 6a and b. The attack observed on the cathode was probably caused by cathodic corrosion attack. $\mathrm{OH}^{-}$produced by reduction of oxygen locally increased the $\mathrm{pH}$ to values where the passive film was chemically dissolved [54]. Corrosion continued even under conditions where the net current was cathodic.

Table 3

Summary of potential and cell current with and without 5mM clear metavanadate additions for the A2024-AA2024 couple

\begin{tabular}{|c|c|c|c|c|c|c|}
\hline \multirow[t]{2}{*}{ Condition } & \multicolumn{3}{|c|}{ Predicted from polarization plots } & \multicolumn{3}{|c|}{ Measured from split cell test } \\
\hline & $E_{\text {Couple }}(\mathrm{V})$ & $i_{\text {Couple }}\left(\mu \mathrm{A} / \mathrm{cm}^{2}\right)$ & 象 reduction & $E_{\text {Couple }}(\mathrm{V})$ & $i_{\text {Couple }}\left(\mu \mathrm{A} / \mathrm{cm}^{2}\right)$ & \% reduction \\
\hline Anode (no-inhibitor) ||cathode (no-inhibitor) & -0.63 & 6.18 & - & -0.829 & -0.56 & - \\
\hline Anode $\left(\mathrm{V}_{1}\right) \|$ cathode (no-inhibitor) & -0.59 & 1.76 & 70 & -.074 & -0.53 & - \\
\hline Anode (no-inhibitor) ||cathode $\left(V_{1}\right)$ & -0.931 & 0.071 & 98 & -0.88 & -0.096 & 78 \\
\hline Anode $\left(\mathrm{V}_{1}\right) \|$ cathode $\left(\mathrm{V}_{1}\right)$ & -0.931 & 0.071 & 98 & -0.88 & -0.096 & 78 \\
\hline
\end{tabular}


It was of interest to investigate whether the attack originated during the initial 15-20 min of stabilization when both half-cells were exposed to the base $0.5 \mathrm{M} \mathrm{NaCl}$ solution. Micrographs of an anode and a cathode after $15 \mathrm{~min}$ of exposure to solutions containing no inhibitor are shown in Fig. 6c and d. Corrosion attack occurred in both sides and had a morphology similar to the morphology observed in Fig. 6a and b. These results indicate that the attack occurred during the initial minutes of stabilization even though the cell potential was well below the pitting potential of AA2024-T3.

Previous findings showed that orange decavanadate solutions did not have a significant effect on the kinetics of the ORR [39]. The effects of injecting orange decavanadate solutions to the AA2024/Cu split cell are shown in Fig. 7. After injecting orange decavanadate solution into the AA2024 anode, there was no net change in galvanic current, which remained at about -55 $\mu \mathrm{A}$. Immediately after injection of the orange decavanadate solution into the Cu-cathode side, a current spike of $-160 \mu \mathrm{A}$ and a potential spike to $-0.45 \mathrm{~V}$ SCE were observed. In contrast to the sharp current spikes associated with reduction of $\mathrm{Cr}^{6+}$ to $\mathrm{Cr}^{3+}$, this current transient associated with injection of decavanadates had a longer duration (i.e. the time to reach the current level measured before injecting the inhibitor) of approximately 7-8 min. Thereafter, the net galvanic current slightly decreased and, after $90 \mathrm{~min}$, a reduction in galvanic current of $42 \%$ was observed. Similar results were obtained when the orange decavanadate solution was first injected to the Cu-cathode side. Table 4 summarizes the results for the injection of orange decavanadate solutions to the AA2024/Cu split cell.

Since in all the experiments corrosion of the anode took place during the initial minutes, it was of interest to investigate the effects of introducing the vanadate solution to the anode or to the cathode from the beginning of the test, before immersing the samples. The experiment started immediately after immersion. The AA2024/Cu cell was chosen for two reasons: (a) the corrosion attack on the anode side was clearly observable with the unaided eye and (b) injection of the clear metavanadate solutions into the $\mathrm{Cu}$ side had a significant effect on the galvanic current.
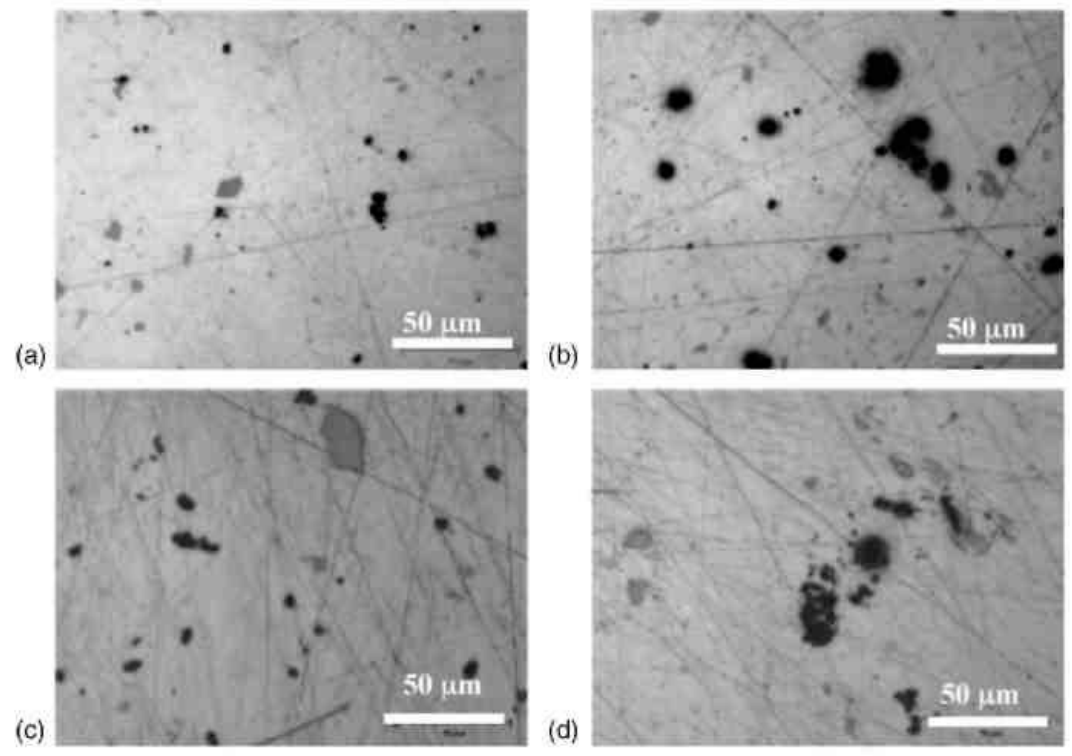

(c)

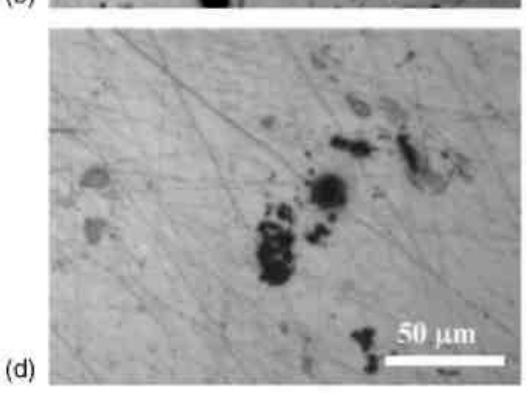

Fig. 6. Optical micrographs of (a) anode and (b) cathode of an AA2024/AA2024 split cell after the entire experiment (experiment shown in Fig. 5), (c) AA2024 anode and (d) cathode of an AA2024/AA2024 split cell after 15 min with no inhibitor injected. 

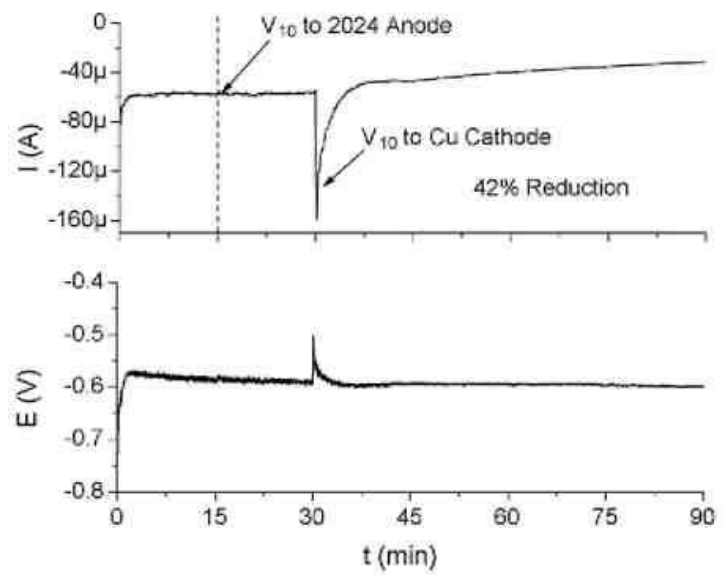

Fig. 7. AA2024/Cu split cell. Orange decavanadate solution injected into anode (AA2024-T3) side first and to the cathode $(\mathrm{Cu})$ later.
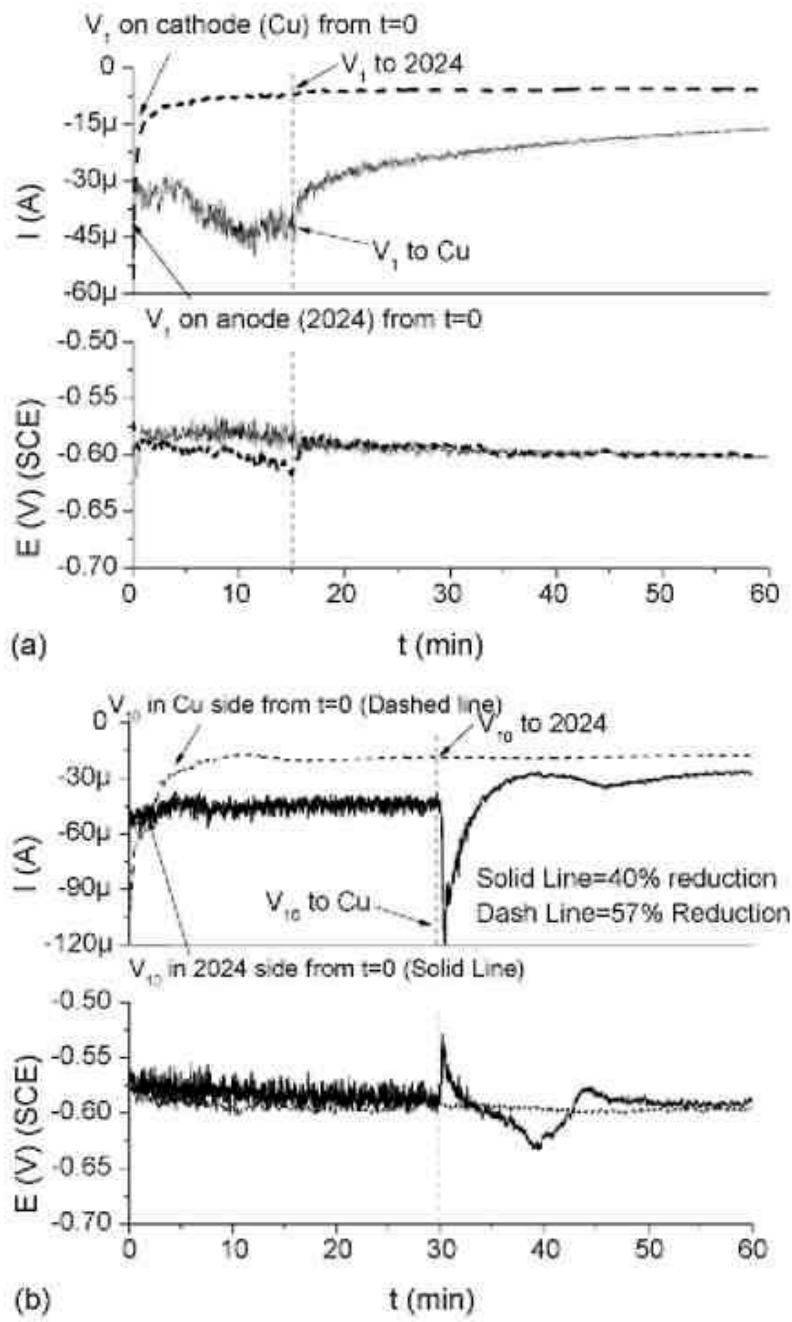

Fig.8. Effects of injection of (a) clear metavanadate and (b) orange decavanadate solutions into the cathode (dash line) or to the anode (solid line) from $t=0 \mathrm{~s}$. Orange decavanadate injected later into the other half cell as indicated. 
Fig. 8a summarizes the variations in the galvanic current and potential of the cell when clear metavanadate solution was added to the AA2024-anode side (solid line) or to the $\mathrm{Cu}$ cathode side (dashed line) from $t=0 \mathrm{~min}$. The presence of metavanadate in the anode side from the beginning of the test did not have an appreciable effect on galvanic current, which varied from about -30 to $-45 \mu \mathrm{A}$. Injection of clear metavanadate solution to the $\mathrm{Cu}$-cathode at $15 \mathrm{~min}$ produced a rapid reduction in the galvanic current of approximately 65\%. A micrograph of the AA2024-T3 anode after the 60 min of exposure can be observed in Fig. 9a. The surface of the sample suffered severe pitting and precipitation of dark-yellow corrosion products rich on vanadium was observed during the test. In contrast, when the metavanadates were present on the $\mathrm{Cu}$-cathode from the beginning of the test, a significant reduction in galvanic current was obtained. Considering that in the absence of the inhibitor the galvanic current generally reached 45 to $-55 \mu \mathrm{A}$, a net reduction in galvanic current of about $90 \%$ was measured. Injecting the clear metavanadate solution to the anode at 15 min did not have any appreciable effect. The extent of the attack was dramatically reduced by the presence of metavanadates on the Cu-cathode from $t$ $=0 \mathrm{~min}$, Fig. 9b. Only small pits were observed after the 60 min experiment. The potential of the cell did not vary appreciably during the test.

The effects of introducing the orange decavanadate solution to the AA2024-anode side (solid line) or to the Cu-cathode side (dash line) from the beginning of the test are summarized in Fig. 8b. In good agreement with previous results, the presence of the decavanadate solution in the anode side from the beginning of the test did not affect the galvanic current, which reached approximately $-57 \mu \mathrm{A}$. Injecting the orange decavanadate solution to the cathode at $30 \mathrm{~min}$ produced a current peak that reached $-130 \mu \mathrm{A}$ and lasted approximately $10 \mathrm{~min}$. After the $60 \mathrm{~min}$ of experiment, a net reduction of $40 \%$ in the galvanic current was observed. Adding the orange decavanadate solution to the $\mathrm{Cu}$-cathode from $t=0$ min reduced the galvanic current by about 57\%. Injecting the decavanadates to the AA2024-anode at $30 \mathrm{~min}$ had no significant effect. In all experiments, samples suffered severe corrosion attack, which was characterized by the precipitation of a dark-yellow corrosion product.

Table 4

Summary of potential and cell current with and without $5 \mathrm{mM}$ orange decavanadate additions for the A2024/Cu couple

\begin{tabular}{|c|c|c|c|c|c|c|}
\hline \multirow[t]{2}{*}{ Condition } & \multicolumn{3}{|c|}{ Predicted from polarization plots } & \multicolumn{3}{|c|}{ Measured from split cell test } \\
\hline & $E_{\text {Couple }}(\mathrm{V})$ & $i_{\text {Couple }}\left(\mu \mathrm{A} / \mathrm{cm}^{2}\right)$ & $\%$ reduction & $E_{\text {Couple }}(\mathrm{V})$ & $i_{\text {Couple }}\left(\mu \mathrm{A} / \mathrm{cm}^{2}\right)$ & \% reduction \\
\hline 2024 (no-inhibitor) $\| \mathrm{Cu}$ (no-inhibitor) & $-0.57 /-0.63$ & 271.83 & - & -0.59 & -190 & - \\
\hline $2024\left(\mathrm{~V}_{10}\right) \| \mathrm{Cu}$ (no-inhibitor) & -0.54 & 229.1 & - & -0.59 & -190 & - \\
\hline 2024 (no-inhibitor) $\| \mathrm{Cu}\left(\mathrm{V}_{10}\right)$ & $-0.571-0.63$ & 271.83 & - & -0.59 & -97 & 48 \\
\hline $2024\left(\mathrm{~V}_{10}\right) \| \mathrm{Cu}\left(\mathrm{V}_{10}\right)$ & -0.54 & 229.1 & - & -0.59 & -97 & 48 \\
\hline
\end{tabular}

\section{Discussion}

The partial or complete separation of anodic and cathodic reactions achieved by the split cell permits the investigation of both inhibition effects and mechanisms. However, as explained by Clark et al. [33], the spatial separation of the anode and the cathode decreases the local chemical interactions between surface sites. Nevertheless, taking into account such limitation, interesting and useful information can be extracted from the data presented here. 


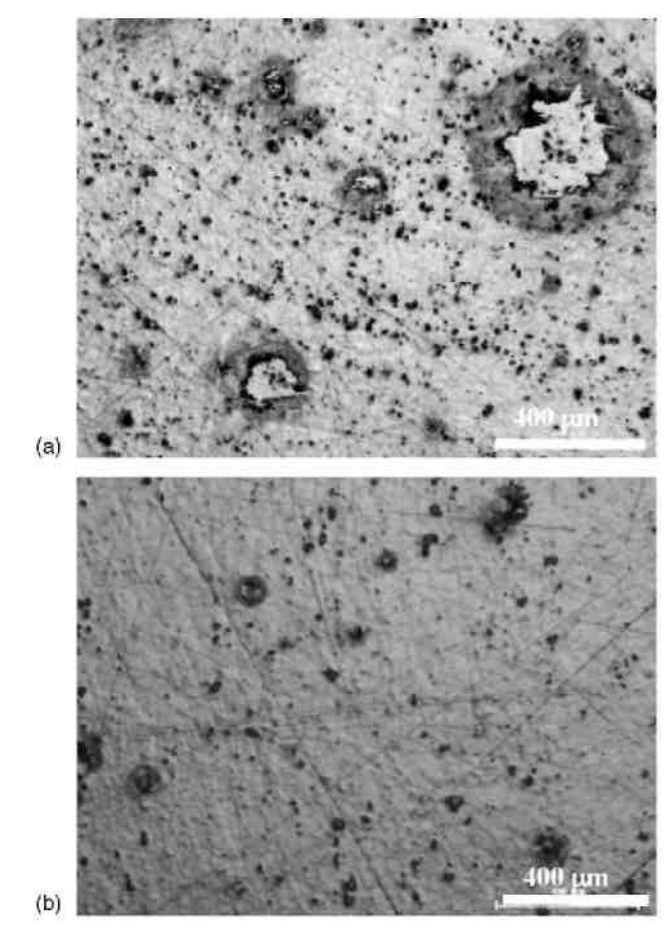

Fig. 9. AA2024 anode of an AA2024/Cu split cell where clear metavanadate solution was added from $t=0 \mathrm{~s}$ into (a) the anode side or $(\mathrm{b})$ the cathode side $(\mathrm{Cu})$.

Separation of anodic and cathodic reactions for the $\mathrm{Al} / \mathrm{Cu}$ split cells was evident, even when both sides were in aerated but stagnant conditions (Fig. 2). The galvanic current of the $\mathrm{Al} / \mathrm{Cu}$ split cell was greatly controlled by aeration or solution stirring on the Cu-cathode side, indicating that the rate of $\mathrm{O}_{2}$ reduction on the $\mathrm{Cu}$-cathode was the rate determining step (Fig. 2).

Separation of anodic and cathodic reactions of AA2024/Cu and AA2024/AA2024 was not complete. Therefore, the measured galvanic current did not represent the total current. Local cathodes associated with IMCs on the AA2024 surface could still support the ORR, even when the net current was anodic. Likewise, local anodes associated with S-phase particles could still suffer selective dissolution even when the net current was cathodic [10]. The micrographs shown in Figs. 6 and 9 indicate that the attack on AA2024 anodes and cathodes was associated with IMCs. The fact that the AA2024-cathodes of the AA202/AA2024 split cells showed more visual damage than the anodes was related to cathodic attack of the matrix surrounding the IMCs.

Injection of clear metavanadate solution to the anode side of $\mathrm{Al} / \mathrm{Cu}, \mathrm{AA} 2024 / \mathrm{Cu}$ and AA2024/AA2024 split cells had no appreciable effect on the galvanic current, even when the inhibitor was present before starting the tests (Figs. 3-5 and 8a). These findings suggest that clear metavanadate solutions exerted no control over the anodic dissolution reactions. In contrast, injection of clear metavanadate solutions to the cathode side produced a rapid reduction in galvanic current, the extent of which depended on the type of split cell tested. For the $\mathrm{Al} / \mathrm{Cu}$ split cell, this reduction in galvanic current was small, averaging 36\% (Table 1). Reduction in galvanic current was significantly larger for the AA2024/Cu split cell, $77 \%$ as shown in Table 2. The largest percentage of reduction was found for the AA2024/AA2024 split cells. On average, a reduction of the galvanic current of $78 \%$ was observed (Table 3). Interestingly, in all cases, injection of clear metavanadate solutions to the cathode side was never accompanied by a current spike associated with vanadate reduction. These findings show a contrast with injection of $\mathrm{Cr}^{6+}$, 
suggesting a different mechanism of inhibition. In both cases, injection of the inhibitor to the cathode significantly reduced the galvanic current, indicating a potent inhibition of the ORR. In the case of $\mathrm{Cr}^{6+}$ injection, it was hypothesized that the formation of a $\mathrm{Cr}^{3+}$ monolayer by reduction of $\mathrm{Cr}^{6+}$ blocked the transfer of electrons through the film [53]. The reduction of $\mathrm{Cr}^{6+}$ was referred to as self-limiting since no further $\mathrm{Cr}^{6+}$ reduction was observed after the first monolayer was formed [33,53]. The ORR was also impeded after formation of the $\mathrm{Cr}^{3+}$ layer, which reduced the corrosion rate $[33,53]$. The galvanic current was decreased by the injection of clear metavanadate solution, but no spike was observed. Furthermore, incremental amounts of clear metavanadate solution added to the cathode side had no appreciable effect. Adding the inhibitor to the cathode before starting the tests resulted in the largest reduction in galvanic current, Fig. 8a. When inhibitor was absent during the initial $15 \mathrm{~min}$, pitting corrosion was initiated on the anode, making the subsequent anodic dissolution easier. Injection of the clear metavanadate solution into the cathode slowed the anodic dissolution by controlling the kinetics of the ORR. Consequently, when metavanadates were present from the beginning of the test, pitting was suppressed or reduced by the initially lower rate of oxygen reduction. The result was a noticeably lower galvanic current, which represented a reduction of $90 \%$ when compared with the average current measured in the absence of inhibitor. The absence of a current spike suggests that metavanadates act by forming a film via absorption or chemisorption rather than reduction. The adsorption of metavanadates on different substrates is the topic of a future communication.

Previous results indicated that the rate of the ORR in orange solutions containing decavanadates was only slightly lower than in the base solution with no vanadate [39]. Thus, when testing decavanadates by the split cell, a smaller reduction in galvanic current was to be expected. However, as shown in Figs. 7 and 8b, a different electrochemical behavior was observed. Injecting orange solutions containing decavanadates to the anode side had no appreciable effect on the galvanic current. On the other hand, injection of orange solutions to the $\mathrm{Cu}$-cathode resulted in a current peak of prolonged duration and a relatively small reduction in galvanic current after the 90 min of experiment. Integration of the peaks showed that the charge associated with the transient event was $3.3 \pm 0.3 \mathrm{mC} / \mathrm{cm}^{2}$. Using Faraday's law and assuming the reduction of $\mathrm{V}^{5+}$ to $\mathrm{V}^{4+}$ ( 1 equiv./mol), the charge is equivalent to $3.38 \times 10^{-8} \mathrm{~mol} / \mathrm{cm}^{2}$ of the reduced specie. Clark et al. reported that the charge associated with the reduction of $\mathrm{Cr}^{6+}$ was approximately $5 \times 10^{-9} \mathrm{~mol} / \mathrm{cm}^{2}$ [53]. The consequence of the reduction of chromate was the formation of a monolayer of $\mathrm{Cr}^{3+}$. To qualitatively compare the split cell results obtained for decavanadate solutions with results obtained for chromates, the current peaks were integrated. It was assumed that the current peaks resulted in the formation of reduced species that were deposited onto the surface with 100\% efficiency. The decavanadate molecule is larger than the chromate and dichromate molecules and it is not completely symmetric. Considering that the average diameter of a decavanadate molecule is approximately 760pm [42], $3.38 \times 10^{-8} \mathrm{~mol} / \mathrm{cm}^{2}$ implies the formation of about 10 monolayers. This suggests the formation of a film that was not self-limiting.

A better understanding of the behavior of the different split cells can be obtained by analyzing anodic and cathodic polarization curves. To simulate the conditions present during split cell tests, anodic polarization curves of pure Al and AA2024-T3 were carried out in deaerated conditions and gentle agitation. Cathodic polarization curves were obtained in aerated conditions with stirring. Experiments were repeated in triplicate at minimum. In all cases the solution $\mathrm{pH}$ was adjusted to 7.6. The polarization curves shown here represent the average behavior. 


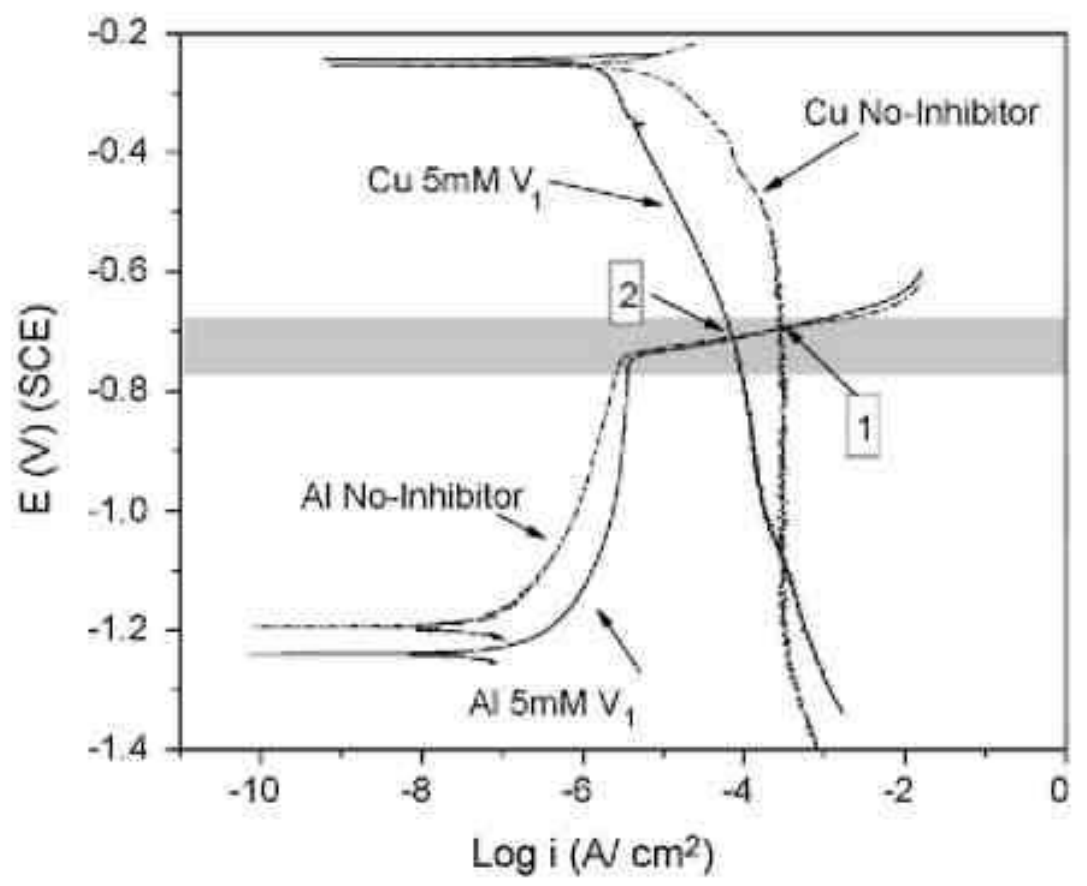

Fig. 10. Cathodic polarization curves of $\mathrm{Cu}$ in aerated conditions and anodic polarization curves of pure $\mathrm{Al}$ in deaerated conditions with and without addition of clear metavanadates. The shadowed region indicates the range of potentials measured during the split cell tests.

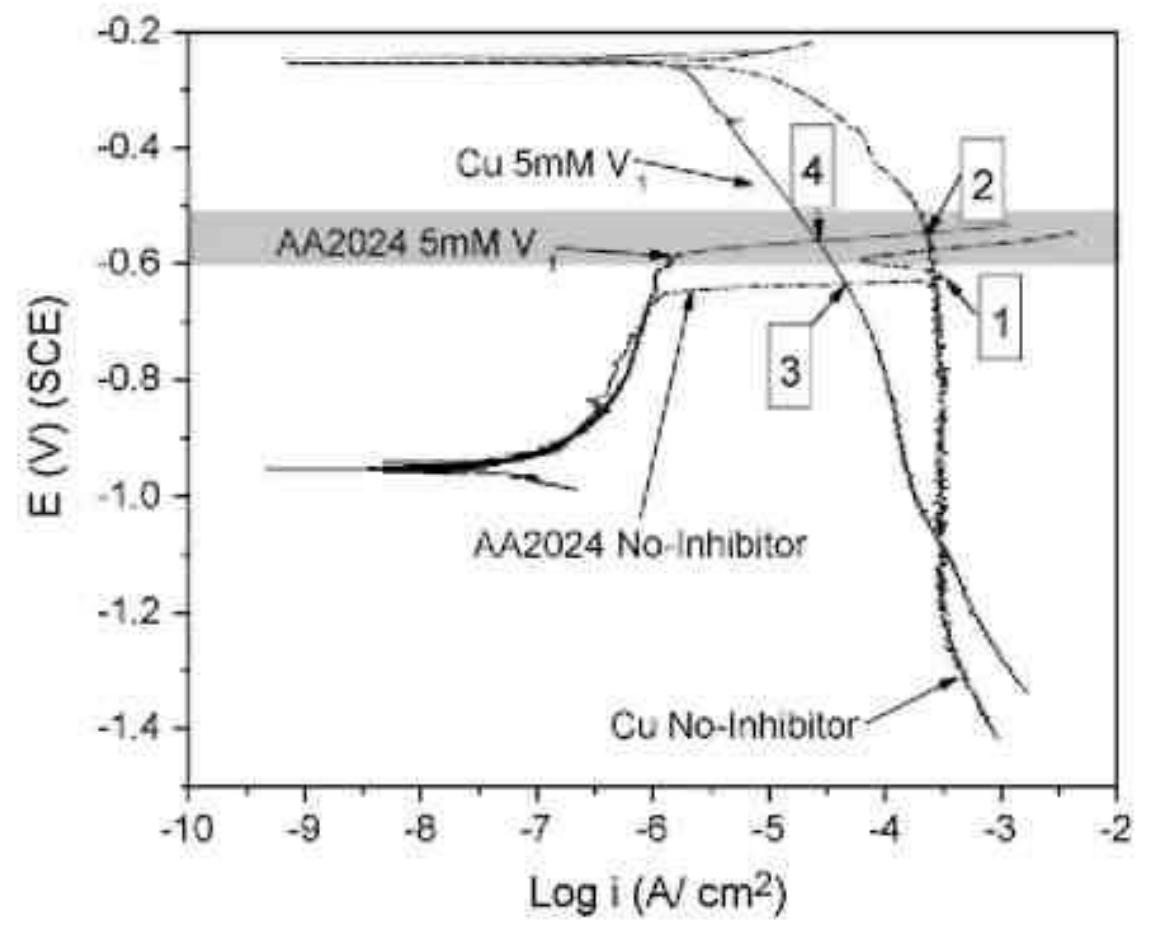

Fig. 11. Cathodic polarization curves of $\mathrm{Cu}$ in aerated conditions and anodic polarization curves of AA2024-T3 in deaerated conditions with and without additions of clear metavanadates. The shadowed region indicates the range of potentials measured during the split cell tests. 


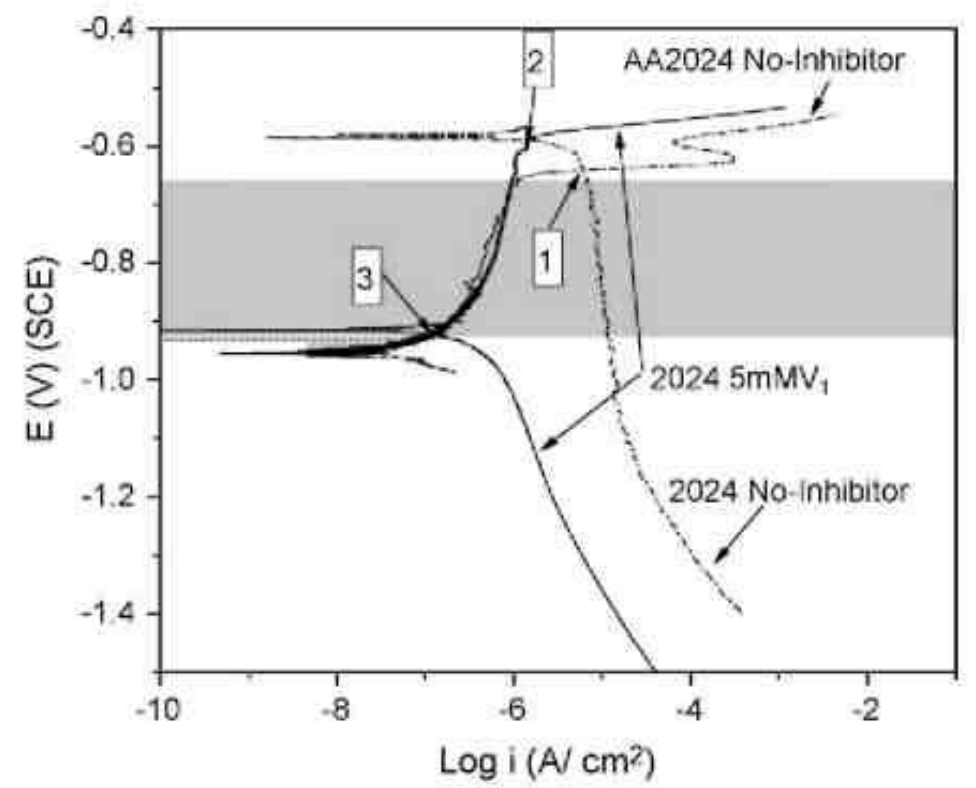

Fig. 12. Cathodic polarization curves in aerated conditions and anodic polarization curves in deaerated conditions both for AA2024-T3 with and without additions of clear metavanadates. The shadowed region indicates the range of potentials measured during the split cell tests.

An overlay of anodic and cathodic polarization curves of $\mathrm{Al}$ and $\mathrm{Cu}$ is shown in Fig. 10. Anodic polarization curves of $\mathrm{Al}$ in deaerated $0.5 \mathrm{M} \mathrm{NaCl}$ with no inhibitor showed an OCP of approximately $-1.15 \mathrm{~V}$ SCE. A passive region was observed above the OCP with a passive current density of approximately $0.5 \mu \mathrm{A} / \mathrm{cm}^{2}$. A pitting potential $\left(E_{\mathrm{P}}\right)$ of $-748 \mathrm{mV}$ SCE was observed. In solutions containing $0.5 \mathrm{M} \mathrm{NaCl}+5 \mathrm{mM}$ clear metavanadate (approximately 1.6 $\mathrm{mM}$ monovanadate [39]), no significant changes were observed. The OCP was on average 50 $\mathrm{mV}$ lower than in the absence of the inhibitor. The passive current was slightly higher, ranging from 0.8 to $1 \mu \mathrm{A} / \mathrm{cm}^{2}$. The $E_{\mathrm{P}}$ was the same with or without the inhibitor, showing that the presence of clear metavanadate did not affect the anodic reaction (in this case localized $\mathrm{Al}$ dissolution). Cathodic polarization curves of $\mathrm{Cu}$ in aerated $0.5 \mathrm{MNaCl}$ electrolytes with no inhibitor added are characterized by a large limiting current $\left(i_{\mathrm{L}}\right)$ of about $-320 \mu \mathrm{A} / \mathrm{cm}^{2}$ due to the strong stirring and air bubbling of the electrolyte [55-57]. Evolution of hydrogen gas was observed at potentials below $-1.2 \mathrm{~V}$ SCE. The OCP was very reproducible in the range of -240 to $-250 \mathrm{mV}$ SCE. Additions of clear metavanadate solution to give $1.6 \mathrm{mM}$ monovanadate had a significant effect on the shape of the $\mathrm{Cu}$ cathodic polarization curves. The cathodic current was noticeably reduced by the presence of the inhibitor, especially at higher potentials. In addition, there was no clear limiting current region and, at potentials lower than -1.1 V SCE, the cathodic current became greater than the current in the absence of the inhibitor. Assuming insignificant IR drop between cells, and since the electrode areas were equal, the electrochemical response of each electrode upon galvanic coupling in the split cell can be predicted from the intersection of these curves. The shadowed region in Fig. 10 indicates the mixed potential measured during split cell tests. According to Fig. 10, coupling $\mathrm{Al}$ with $\mathrm{Cu}$ always polarized $\mathrm{Al}$ above its pitting potential (points 1 and 2) resulting in the observed severe localized corrosion attack. Table 1 summarizes the potential and current of the different coupling combinations as well as the expected change in galvanic current from the addition of metavanadates. The change in current 
predicted from the polarization curves was larger than the observed change. The potential of the couples during the split cell test was in good agreement with the intersection of the polarization curves.

Anodic polarization curves of AA2024-T3 in deaerated $0.5 \mathrm{M} \mathrm{NaCl}$ with no inhibitor are characterized by a double breakdown potential [10]. The first breakdown potential $\left(E_{\mathrm{P} 1}\right)$ is related to the transient dissolution of S-phase particles and the second one $\left(E_{\mathrm{P} 2}\right)$ to matrix and intergranular attack [10]. Fig. 11 shows an overlay of anodic and cathodic polarization curves for AA2024-T3 and $\mathrm{Cu}$, respectively. Interestingly, anodic polarization curves of AA2024-T3 were affected by the presence of $5 \mathrm{mM}$ metavanadate. As can be observed, the first breakdown potential was not present when metavanadate was added. The observed pitting potential was similar to $E_{\mathrm{P} 2}$ in the absence of metavanadates. Since $E_{\mathrm{P} 1}$ is related to dissolution of $\mathrm{Al}_{2} \mathrm{CuMg}$, the absence of such transient event seems to indicate that the clear metavanadate solutions suppressed the dissolution of S-phases until the potential reached $E_{\mathrm{P} 2}$. As explained by Ilevbare and Scully [55,56], reducing the dissolution of $\mathrm{Al}_{2} \mathrm{CuMg}$ particles reduces the formation of $\mathrm{Cu}$ rich cathodic sites. In most of our experiments, however, AA2024-T3 samples were exposed to $0.5 \mathrm{M} \mathrm{NaCl}$ for at least 15 min before injecting the inhibitors. As shown in Fig. 6, pitting corrosion occurred during this period, and metavanadates still reduced the galvanic current. Even though metavanadates could inhibit S-phase dissolution during OCP exposure, reducing initiation of localized corrosion, the reduction of the cathodic kinetics was more significant.

The intersection of the anodic and cathodic curves for the AA2024/Cu couple shown in Fig. 11 was always above the AA2024 pitting potential (points 1-4). The larger reduction in current observed during split cell tests compared to the $\mathrm{Al} / \mathrm{Cu}$ couple can be attributed to the higher intersection potential where the influence of metavanadates on the oxygen reduction kinetics on $\mathrm{Cu}$ was larger. In addition, the polarization curves shown in Fig. 11 indicate that a potential shift would have been expected when injecting the inhibitor in the anode side after first injecting clear metavanadate solutions into the cathode half-cell (from point 3 to 4). However, no such effect was detected. The absence of a potential shift is likely a consequence of the attack suffered by S-phase particles during the initial stabilization period. Anodic polarization curves of AA2024-T3 samples pre-exposed to $\mathrm{Cl}^{-}$containing electrolytes showed only one breakdown potential similar to $E_{\mathrm{P} 2}$. Table 2 summarizes mixed potential and galvanic current for the different cell conditions as well as the expected reduction in galvanic current when the inhibitor was added. In the AA2024/Cu case, the predicted potential and current were both in good agreement with experimental observations during split cell tests.

Fig. 12 shows polarization curves relevant to the AA2024/AA2024 couple. The cathodic polarization curves were in aerated solutions with stirring and the anodic polarization curves were in deaerated solutions with gentle agitation. In the absence of inhibitor, cathodic polarization curves of AA2024-T3 in aerated $0.5 \mathrm{M} \mathrm{NaCl}$ are characterized by a large $i_{\mathrm{L}}$ of about $30 \mu \mathrm{A} / \mathrm{cm}^{2}$ and an OCP of $-590 \mathrm{mV}$ SCE. The intersections of cathodic polarization curves in the absence of inhibitor and anodic polarization curves with or without metavanadates were above the pitting potential (points 1 and 2). The addition of $5 \mathrm{mM}$ clear metavanadate had a remarkable effect on the cathodic kinetics of AA2024-T3, much larger than for $\mathrm{Cu}$. The cathodic current was reduced by almost four orders of magnitude. The OCP was shifted to $-910 \mathrm{mV}$ SCE and hydrogen evolution was observed at lower potentials. This larger reduction of the ORR might be a consequence of the lower active cathode area relative to pure $\mathrm{Cu}$. This large inhibition resulted in a shifting of the steady state intersection point into the passive region of AA2024-T3 and a significant reduction in galvanic current (from point 1 or 2 to point 3). Table 3 summarizes 
mixed potential and galvanic current for the different cell conditions. As shown by the shadowed region in Fig. 12, the potential of the couple was expected to be higher in the absence of inhibitor. Since both anode and cathode sides were always attacked during the initial 15 min stabilization period, it was of interest to evaluate the repassivation potential $\left(E_{R}\right)$ of AA2024-T3 in $0.5 \mathrm{M} \mathrm{NaCl}$ with and without monovanadates. To evaluate $E_{\mathrm{R}}$, AA2024-T3 samples were potentiodynamically polarized from the OCP to a value above $E_{\mathrm{P} 2}$ in $\mathrm{NaCl}$ with and without metavanadates. The direction of the scan was reversed when the current reached $2 \mathrm{~mA} / \mathrm{cm}^{2}$. The repassivation potential was defined as the zero current potential on the reverse scan. In both cases, and in good agreement with previous findings [10], $E_{\mathrm{R}}$ was approximately $-900 \mathrm{mV}$ SCE. The $E_{\mathrm{R}}$ was, therefore, slightly higher than the intersection point of the anodic polarization curves with the cathodic polarization curve in the presence of the inhibitor. Above $E_{\mathrm{R}}$ metastable pits can stabilize and grow as stable pits [10], which could explain the attack observed during AA2024/AA2024 split cell tests at mixed potentials below $E_{\mathrm{P} 1}$.

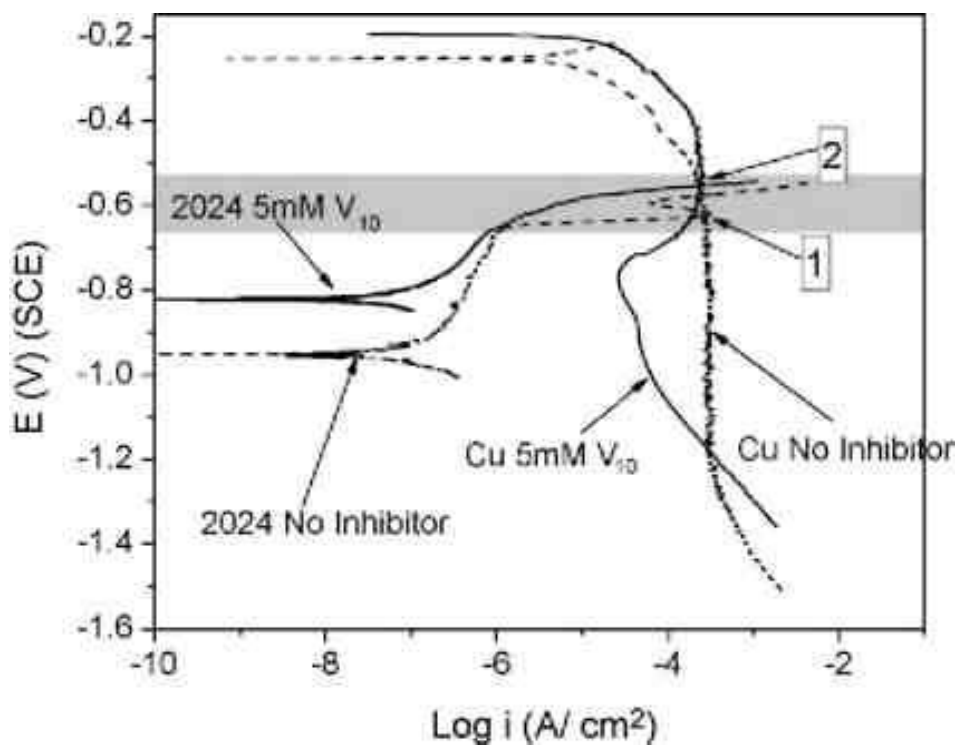

Fig. 13. Cathodic polarization curves of $\mathrm{Cu}$ in aerated conditions and anodic polarization curves of AA2024-T3 in deaerated conditions with and without additions of orange decavanadates. The shadowed region indicates the range of potentials measured during the split cell tests.

Polarization curves for AA2024 and pure Cu with and without 5mM orange decavanadate solutions (approximately $0.45 \mathrm{mM}$ decavanadate) are shown in Fig. 13.The $E_{\mathrm{P} 1}$ was absent in anodic polarization curves of AA2024-T3 in electrolytes containing decavanadates. The observed pitting potential was similar to $E_{\mathrm{P} 2}$ in the absence of inhibitor. The open circuit potential in the presence of decavanadate was larger than the OCP in $0.5 \mathrm{M} \mathrm{NaCl}$ with no inhibitor in deaerated conditions. Anodic polarization curves at varied decavanadate concentrations revealed that at least $5 \mathrm{mM}$ total vanadate is required to protect S-phase dissolution [45]. As in the case of monovanadates, decavanadates might inhibit pit initiation by controlling the initiation of the attack of S-phase particles. The presence of decavanadate also affected the cathodic kinetics of Cu. The OCP was significantly higher, reaching -190mV SCE. A limiting current of $320 \mu \mathrm{A} / \mathrm{cm}^{2}$ was observed until a potential of $-590 \mathrm{mV}$ SCE was reached. At lower potentials, the current decreased to $26 \mu \mathrm{A} / \mathrm{cm}^{2}$ and monotonically increased with decreasing potential thereafter. A similarly anomalous behavior was reported by Scully and 
coworkers for molybdates on $\mathrm{Cu}$ electrodes [58]. The decay in current that occurred at approximately $-650 \mathrm{mV}$ SCE, could be related to the formation of a surface film that reduced charge transference. As in the case of molybdates [26], the subsequent increase in current is possibly the result of the electrochemical reduction of the surface film.

In all cases, the intersection of anodic and cathodic polarization curves was above the pitting potential (points 1 and 2). Even though decavanadates reduced anodic dissolution of Sphases, the small reduction of the ORR resulted in a severe attack on the anode surface during split cell experiments.

\section{Conclusions}

The nature of inhibition by clear metavanadate solutions containing monovanadates and orange solutions containing decavanadates but no monovanadates were investigated by the split cell technique and polarization curves. The use of the split cell technique allows segregation of anodic and cathodic reactions and investigation of the effects of inhibitors on each reaction independently. The following conclusions can be obtained:

1. Injection of clear solutions containing monovanadates to make $5 \mathrm{mM}$ total vanadate after dilution greatly lowered the rate of oxygen reduction on both $\mathrm{Cu}$ and AA2024-T3 cathodes during split cell experiments. Injection of clear metavanadate solutions was followed by an immediate reduction in galvanic current with no current spike representing vanadate reduction.

2. Injection of clear metavanadate solutions to the anode side of the different split cells did not reduce the galvanic current, indicating that vanadate does not inhibit active pits.

3. Anodic polarization curves showed that metavanadates eliminated the transient dissolution of $\mathrm{Al}_{2} \mathrm{CuMg}$. The first breakdown was absent in chloride solutions containing $5 \mathrm{mM}$ clear metavanadate.

4. Cathodic polarization curves indicated a strong decrease in the rate of oxygen reduction by clear metavanadate solutions. In aerated electrolytes, a reduction in current of about four orders of magnitude was observed.

5. Pitting of the AA2024-anodeofthe AA2024/Cu split cell was virtually suppressed when the clear metavanadate solution was added to the Cu-cathode from the beginning of the test.

6. Decavanadates are not good inhibitors of the ORR. Decavanadates showed a sharp current spike after injection on the cathode side of the AA2024/Cu split cell. The intersection point of anodic and cathodic polarization curves was always above the pitting potential of AA2024-T3. Adding decavanadates to either the anode or the cathode of the AA2024/Cu split cell from the beginning of the test did not improve protection. In all cases the AA2024anode was severely pitted after the tests.

7. Even though anodic polarization curves showed that decavanadates reduced the selective dissolution of S-phase particles, these effects seem to be insufficient to reduce corrosion rate.

\section{Acknowledgments}

This work was partially funded by AFOSR under award F 49620-02-0321, Major J. Gresham, PhD, contract monitor. JK's travel expenses were paid by NATO under grant PST.CLG.979370. 


\section{References}

[1] J.R. Davis, ASM Specialty Handbook: Aluminum and Aluminum Alloys, 2nd ed., ASM International, Materials Park, OH, 1993, p. 31 (Chapter 2).

[2] C. Kammer, Aluminum Handbook, vol.1, 1st ed., Aluminum-Verlag, 1999,p. 125 (Chapter 4).

[3] I.J. Polemar, Light Alloys, 3rd ed., Arnold, London, 1995.

[4] N. Birbilis, R.G. Buchheit, J. Electrochem. Soc. 152 (2005) B140.

[5] C. Blanc, B. Lavelle, G. Mankowski, Corros. Sci. 39 (1997) 495.

[6] R.G. Buchheit, J. Electrochem. Soc. 142 (1995) 3994.

[7] G.S. Chen, M. Gao, R.P. Wei, Corrosion 52 (1996) 8.

[8] W. Zhang, G.S. Frankel, J. Electrochem. Soc. 3 (2000) 268.

[9] W. Zhang, G.S. Frankel, J. Electrochem. Soc. 149 (2002) B510.

[10] W. Zhang, G.S. Frankel, Electrochem. Acta 48 (2003) 1193.

[11] P. Leblanc, G.S. Frankel, J. Electrochem. Soc. 149 (2002) B239.

[12] P. Schmutz, G.S. Frankel, J. Electrochem. Soc. 145 (1998) 2285.

[13] P. Schmutz, G.S. Frankel, J. Electrochem. Soc. 145 (1998) 2295.

[14] P. Schmutz, G.S. Frankel, J. Electrochem. Soc. 146 (1999) 4461.

[15] R.G. Buchheit, R.P. Grant, P.F. Hlava, B. McKenzie, G.L. Zender, J. Electrochem. Soc. 144 (1997) 2621.

[16] E. Ghali, Uhlig's Corrosion Handbook, 2nd ed., CANMET Materials Laboratory, Ottawa, Ontario, Canada, 1998 (Chapter 44).

[17] I.L. Muller, J.R. Galvele, Corros. Sci. 17 (1977) 179.

[18] R.G. Buchheit, ECS PV2002-13, Pennington, NJ, 2002, p. 430. a Acta 52 (2007) 4032-4042

[19] P. Campestrini, H.Terryn, J. Vereecken, J.H.W.D. Wit, J. Electrochem. Soc. 151 (2004) B370.

[20] G.S. Frankel, R.L. McCreery, Interface (2001) 34.

[21] P.L. Hagans, C.M. Haas, ASM Handbook, vol. 5, Surface Engineering, 10th ed., ASM International, Metals Park, OH, 1994, p. 405.

[22] M. Kendig, R.G. Buchheit, Corrosion 59 (2003) 379.

[23] M. Kendig, C. Yan, J. Electrochem. Soc. 151 (2004) B679.

[24] M. Koudelkova, J. Augustynski, H. Berthou, J. Electrochem. Soc. 124 (1977) 1165.

[25] P.G. Sheasby, R.Pinner, The Surface Treatment and Finishing of Aluminum and its Alloys, vol. 1,1st ed., ASM International, Materials Park, OH, 2001, p. 231 (Chapter 5).

[26] USAF Blue Ribbon Advisory Panel Report on Aircraft Coatings, Materials Directorate, Wright Laboratory, 1995.

[27] P.Campestrini, G.Goeminne, H. Terryn, J. Vereecken, J. Electrochem. Soc. 151 (2004) B70.

[28] J.S. Crompton, P.R. Andrews, E.M. Alpine, Surf. Int. Anal. 13 (1988) 160.

[29] G.P. Halada, C.R. Clayton, J. Electrochem. Soc. 138 (1991) 2921.

[30] B.L. Hurley, R.L. McCreery, J. Electrochem. Soc. 150 (2003) B367.

[31] C.S. Jeffcoate, H.S. Isaacs, A.J. Aldykiewicz, M.P. Ryan, J. Electrochem. Soc. 147 (2000) 540.

[32] J. Wan, G.E. Thompson, K. Lu, C.J.E. Smith, Physica B 208/209 (1995) 511.

[33] W.J. Clark, J.D. Ramsey, R.L. McCreery, G.S. Frankel, J. Electrochem. Soc. 149 (2002) B179.

[34] J. Zhao, L. Xia, et al., Surf. Coat. Technol. 140 (2001) 51.

[35] M. Kendig, S. Jeanjaquet, R. Addison, J. Waldrop, Surf. Coat. Technol. 140 (2001) 58.

[36] J.H. Osborne, Prog. Org. Coat. 41 (2001) 280.

[37] L. Xia, E. Akiyama, G.S. Frankel, R.L. McCreery, J. Electrochem. Soc. 147 (2000) 2556.

[38] H. Guan, R.G. Buchheit, Corrosion 60 (2004) 284.

[39] M. Iannuzzi, T. Young, G.S. Frankel, J. Electrochem. Soc. 153 (2006).

[40] D.C. Crans, A.S. Tracey, ACS Symp. Ser. 711 (1998) 2.

[41] J.J. Cruywagen, Adv. Inorg. Chem. 49 (2000) 127.

[42] A.F. Holleman,E.Wiberg, Inorganic Chemistry, 2nd ed., Academic Press, Berlin/New York, 2001 (Chapter 26).

[43] L. Petersson, Mol. Eng. 3 (1993) 29.

[44] L. Petterson, K. Elvigson, ACS Symp. Ser. 711 (1998) 30.

[45] M. Iannuzzi, Thesis: Inhibition of Al Alloy 2024-T3 Corrosion by Vanadates, The Ohio State University, 2006.

[46] A. Gorzsas, K. Getty, I. Andersson, L. Petersson, Roy. Soc. Chem., Dalton Trans. (2004) 2873.

[47] E. Heath, O.W. Howarth, J. Chem. Soc., Dalton Trans. (1981) 1105.

[48] A.S. Tracey, Coord. Chem. Rev. 237 (2003) 113. 
[49] A.S. Tracey, J.S. Jaswal, S.J. Angus-Dunne, Inorg. Chem. 34 (1995) 5680.

[50] A.S. Tracey, C.H. Leon-Lai, Inorg. Chem. 30 (1991) 3200.

[51] M. Aureliano, R.M.C. Gandara, J. Inorg. Biochem. 99 (2005) 979.

[52] J.W. Larson, J. Chem. Eng. Data 40 (1995) 1276.

[53] W.J. Clark, R.L. McCreer, J. Electrochem. Soc. 149 (2002) B379.

[54] G.S. Frankel, J.W. Braithwaite, in: P. Marcus, J. Oudar (Eds.), Corrosion Mechanisms in Theory and Practice, 2nd ed., Marcel Dekker, New York, 2002.

[55] G.O. Ilevbare, J.R. Scully, Corrosion 57 (2001) 134.

[56] G.O. Ilevbare, J.R. Scully, J. Electrochem. Soc. 148 (2001) B196.

[57] M.B. Vukmirovic, N. Vasiljevic, N. Dimitrov,K. Sieradzki, J. Electrochem. Soc. 150 (2003) B10.

[58] F.J. Presuel-Moreno, M.A. Jakab, J.R. Scully, J. Electrochem. Soc. 152 (2005) B376. 